\title{
Mediation by Organizational Design in the Influence of Organizational Ambidexterity on the Performance of Large Manufacturing Firms in Kenya
}

\author{
Patrick M. Mutisya ${ }^{1}$, Peter K'Obonyo ${ }^{1}$, Kennedy Ogollah $^{1}$ \& James M. Njihia ${ }^{2}$ \\ ${ }^{1}$ Department of Business Administration, School of Business, University of Nairobi, Nairobi, Kenya \\ ${ }^{2}$ Department of Management Science - School of Business, University of Nairobi, Kenya \\ Correspondence: Patrick M. Mutisya, PhD Candidate, Department of Business Administration, School of Business, \\ University of Nairobi, Nairobi, Kenya. E-mail: pmmutisya@ hotmail.com
}

Received: October 7, 2020

Accepted: November 1, 2020

Online Published: November 15, 2020

doi:10.5430/jms.v11n4p10

URL: https://doi.org/10.5430/jms.v11n4p10

\begin{abstract}
The aim of this study was to establish the role of organizational design in the organizational ambidexterity performance relationship among large manufacturing firms (LMFs) in Kenya. The studies linking ambidexterity to organizational performance are few and with mixed findings. The few studies indicate that there is no clear ambidexterity - organizational performance relationship. The research was founded on dynamic capabilities and configurations theories. Based on the reviewed literature, a conceptual model and hypotheses were formulated. The study was guided by positivist philosophy. The population of the research was the entire 107 Kenyan large manufacturing firms (LMFs). Cross-sectional research design was used. Primary data in respect of predictor variables was used and was collected using a structured questionnaire. The respondents were the senior managers of the large manufacturing firms (LMFs) in Kenya; namely Chief Executive Officers/Managing Directors (CEOs/MDs) or General Managers (GMs), or Heads of departments (HODs). Descriptive statistics, correlations, linear, multiple and hierarchical regressions were applied in the data scrutiny and interpretation. The study results showed partial organizational design mediating role in the organizational ambidexterity - performance association of LMFs in Kenya. The study findings are useful to practitioners and managers of LMFs, policymakers in government as well as scholars and researchers. The study recommends further studies on the mediating role of organizational design, different variable operationalization, diversify respondents and context as well as longitudinal study.
\end{abstract}

Keywords: organizational ambidexterity, mediating role, organizational design, performance, large manufacturing firms in Kenya

\section{Introduction}

\subsection{Background of the Study}

Organizational ambidexterity which is an organization's capability to concurrently explore and exploit has drawn wide research attention in strategic management (O'Reilly \& Tushman, 2013). Exploration whose focus is new knowledge search necessitates adaptability to environmental changes while exploitation ensures current business efficiency and alignment through enhancement and refinement (March, 1991); hence the increasing consensus among strategic management scholars that organizational ambidexterity enhances business sustainability (Tushman \& O'Reilly, 1996). However, tensions emerge from the undertaking of the opposing activities, which require appropriate managerial intervention, without which, organizational ambidexterity cannot be achieved (Andriopoulos $\&$ Lewis, 2010). Thus, despite growing research undertaken on organizational ambidexterity in different contexts and methodologies, the findings are varied (Junni, Sarala, Taras \& Tarba, 2013).

Organizational design intervention has been proposed to address the resultant tensions from the concurrent undertaking of exploration and exploitation activities, thus organizational ambidexterity achievement (Marks, Mathieu \& Zaccaro, 2001). However, the organizational design role in easing the inherent tensions of ambidexterity is considered difficult (O'Reilly \& Tushman, 2008) due to resultant negative externalities (March, 1991). The Kenyan manufacturing sector has the potential to significantly impact the country's economic performance and has been identified as a pillar of the "Big Four" agenda towards achieving the country's vision 2030 (GOK, 2018). 
However, despite the significance, its Gross domestic product (GDP) contribution has declined.

\subsection{Research Problem}

The consensus is increasing among scholars that organizational ambidexterity is important for business sustainability but it is not easily achievable (O'Reilly \& Tushman, 2008). The exploitative and explorative activities in ambidexterity exhibit opposing features, and require diverse structural designs (Raisch \& Birkinshaw, 2008). The resultant tensions and potential intra-organizational conflict may require trade-offs, often resulting in organizations favouring one activity at the expense of the other, thus making organizational ambidexterity difficult (Ghemawat \& Costa, 1993). In addition, organizational ambidexterity is expected to trigger organizational design alignment which eases the tensions, therefore affecting performance (Raisch \& Birkinshaw, 2008). However Lawrence and Lorsch (1967) argue that it is difficult to reconcile organic and mechanistic structures in a single firm. Therefore, full ambidexterity - organizational design alignment is considered difficult (O'Reilly \& Tushman, 2008) due to resultant negative externalities (March, 1991; Raisch \& Zimmerman, 2017), hence a paradox. According to Adler, Goldoftas and Levine (1999) the paradox can be fixed with a combination of organic and mechanistic organizational structures.

The Kenyan manufacturing sector has great prospects for spurring growth in other sectors, including export and is one of the government's "Big Four agenda" pillars towards the attainment of Vision 2030 (GOK, 2018). However, the manufacturing sector GDP contribution declined from 10\% in 2014 to $7.8 \%$ in 2018, while its growth is erratic; $2.5 \%$ in $2014,3.6 \%$ in $2015,3.1 \%$ in $2016,0.7 \%$ in 2017 and $4.3 \%$ in 2018 (KNBS, 2019). The declining performance also suggests that the strategies deployed have not been effective in enhancing performance.

The environmental changes and competition in the sector may require organizational ability to be ambidextrous. This suggests that the manufacturing sector's performance may be influenced by its capacity for ambidexterity. However, it is not clear whether and how organizational ambidexterity influences the performance of Kenya's large manufacturing firms. Also, there are limited studies conducted on organizational ambidexterity in the Kenyan manufacturing sector.

Despite the theoretical ambidexterity-organizational performance nexus, empirical studies testing this relationship are scanty and have yielded inconsistent results (Junni et al., 2013). This inconsistency in the findings suggests that there may be other factors mediating the relationship. Raisch and Birkinshaw (2008) suggested organizational design mediating effect in the organizational ambidexterity - performance relationship. However, researchers have reported mixed findings on this relationship. While some studies (Hill \& Birkinshaw, 2014; Boumgarden, Nickerson \& Zenger, 2012) reported a positive organizational design - organizational ambidexterity - performance association, the organizational design mediating role was not explored. O'Reilly and Tushman (2011) reported a mediating effect of structural mechanisms linked with top management's integration on organizational ambidexterity and performance relationship. Study by Venkatraman, Lee and Lyer (2007) revealed an insignificant organizational design mediating role.

The above empirical studies have reported inconsistent results on the organizational ambidexterity, organizational design, and organizational performance relationships. This study seeks to address the emerging conceptual gaps, contextual, and methodological gaps by answering the question; what is the role of organization design in the relationship between organizational ambidexterity and performance? The study objective is to determine the role of organizational design in the relationship between organizational ambidexterity and performance of large manufacturing firms in Kenya.

\section{Literature Review}

\subsection{Organizational Ambidexterity, Organizational Design, and Performance}

The organization's capability to concurrently pursue two disparate undertakings and with equal dexterity is what is called organizational ambidexterity, namely the organization's capacity to concurrently exploit and explore (March, 1991; O’Reilly \& Tushman, 2013). Scholars have increasingly recognized organizational ambidexterity's major contribution to sustained organization's enhanced performance. However, the reviewed literature by Junni et al. (2013) reveals scanty and mixed organizational ambidexterity - performance linkage research results. The reported mixed findings imply that there are other factors mediating the organizational ambidexterity effect on performance.

There is consensus on the merits of organizational ambidexterity influence on organizational performance or even survival (Junni et al., 2013). This influence is affected by the tensions arising from the pursuance of two contrasting and contradicting activities (Birkinshaw \& Gupta, 2013). Organizational design has been suggested as one of the ways of managing the tensions and therefore achieving ambidexterity impact on performance (Marks, Mathieu \& Zaccaro, 2001). However, researchers have reported mixed findings on the ambidexterity - organizational design and 
performance relationships.

Hill and Birkinshaw (2014) study on Corporate Venture units found a positive association between structural design and ambidextrous orientation development. The study focused on the relationship between structural design and ambidexterity in corporate venture units. The results do not adequately explain the role of structural design in the ambidexterity- performance relationship of the corporate venture units. Boumgarden et al. (2012) study on the relationship between organizational ambidexterity and organizational design found that spatial separation, an aspect of organizational design, aids organizational ambidexterity and therefore enhances performance. However, the study did not explore the role of organizational design in explaining the influence of organizational ambidexterity on performance. O'Reilly and Tushman (2011) reported a mediating effect of structural mechanisms linked with top management's integration on organizational ambidexterity and performance relationship. It is however not clear what the mediator actually was, between structural mechanism and top management integration. Findings of a study by Venkatraman et al. (2007) revealed a weaker and insignificant effect of structural separation, compared to that of temporal separation in ambidexterity effect on performance, as evidenced by their relative effects on sales growth. Kariuki (2015) study findings established a significant influence of structure on Kenyan large manufacturing enterprises' performance. The study focus was on the effect of structure on organizational performance and does not explain the role of organizational design in the influence of organizational ambidexterity on performance.

Despite inconsistency in the research findings of studies on the effect of organizational ambidexterity on performance, there is consistency that structural mechanisms, coupled with top management's overarching vision targeted to leverage assets, enable the organizational ambidexterity effect on performance (Birkinshaw \& Gupta, 2013; Hill \& Birkinshaw, 2014). However, there are very few studies that have explored the role of organizational design in explaining organizational ambidexterity influence on organizational performance. Although a few studies have explored the organizational design mediating role in the organizational ambidexterity-performance relationship, the process through which this happens remains unclear. In particular the role of organizational design in easing the tensions arising from the pursuance of the contradicting and contrasting exploitation and exploration activities. Arising from this, the study seeks to examine how organizational ambidexterity influences organizational performance through organizational design.

\subsection{Conceptual Framework}

The link amongst the three variables under study is shown in Figure 1.1 (conceptual model) below. The variables are organizational ambidexterity, organizational design, and performance of large manufacturing firms (LMFs). Organizational ambidexterity is the predictor variable and performance is the criterion variable, whereas organization design is the mediator variable. Organizational design is conceptualized to mediate because organizations remain relevant if their assembly of structures, processes, and systems facilitate the link of the organization to its environment.

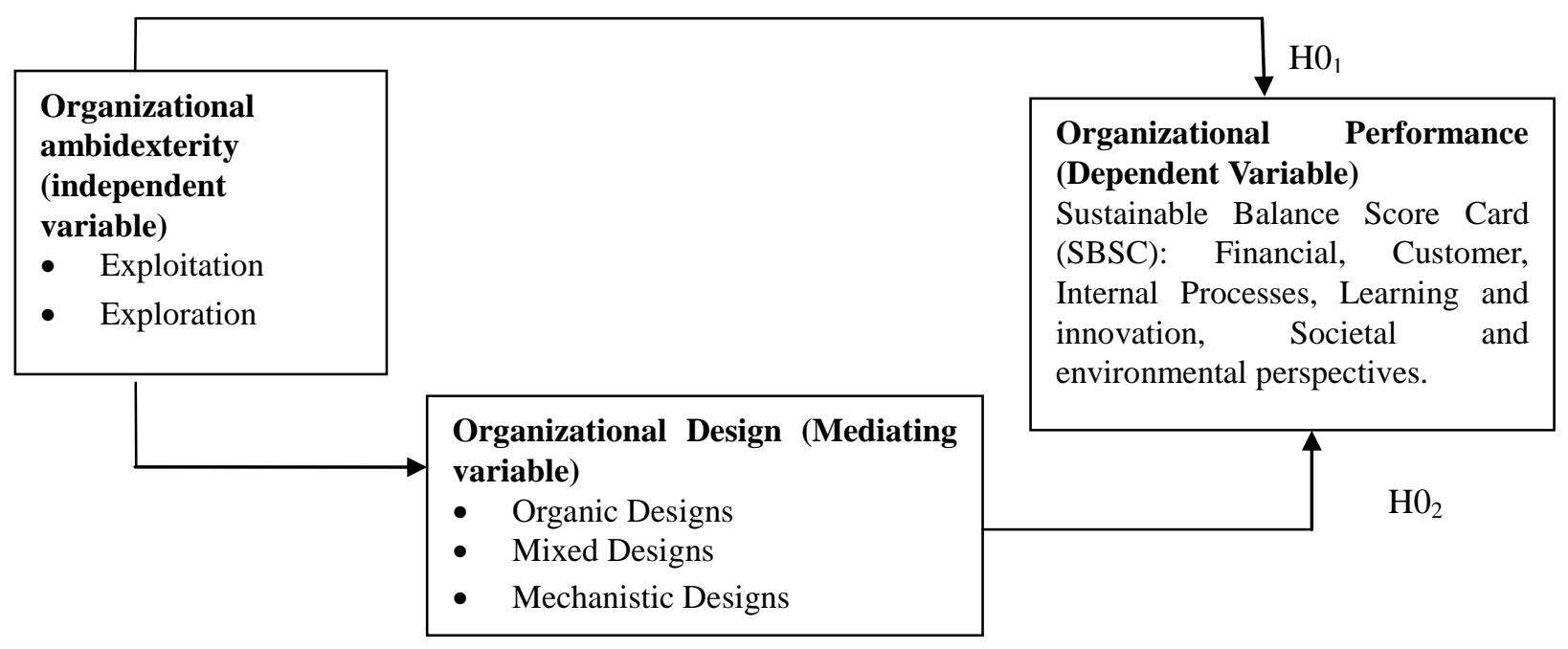

Figure 1. Conceptual Model 


\subsection{Operationalization of the Study Variables}

The study's independent variable, organizational ambidexterity was measured using exploration and exploitation variables. A combined perspective was applied, in which the two activities are considered orthogonal, but complementary, based on which ambidexterity was studied as the summed-up outcome (Blindenbach-Driessen \& Ende, 2014). The measure reliably predicts the ambidexterity synergistic effect and was adapted from Hill and Birkinshaw (2014) in whose similar operational approach it was used.

The mediating variable in this study is organizational design, which was operationalized as evidenced by mechanistic and organic designs. Complexity and centralization, division of labour into specialized functions, rules and procedures, narrow span of control and long command hierarchy characterize mechanistic designs. Being at the two extremes implies that on a scale ranging from organic to mechanistic, the mid-point is mixed organizational designs. These were adapted from past studies (Akdogan, Akdogan \& Cingoz, 2009; Ogollah, 2012). The dependent variable organizational performance, which was measured by adopting measures of performance from sustainable balanced scorecard by Hubbard (2009) that considers six indicators of performance; financial, internal processes, customer satisfaction, learning, and innovation, societal and environmental perspectives, using Likert-scale instrument adopted with modifications from Hubbard (2009).

\subsection{Research Hypotheses}

The following is the hypotheses, stated in null:

$\mathrm{HO}_{1}$ : Organizational design has no mediating role in the influence of organizational ambidexterity on the performance of large manufacturing firms in Kenya.

\subsection{Study Model}

The hypothesis testing was guided by the following model:

Mediating role of organizational design in the influence of organizational ambidexterity on organizational performance using Path Analysis (4-Step):

Based on Organizational performance as a composite of the SBSC perspectives:

Equations:

$$
\begin{gathered}
\mathrm{OP}=\mathrm{f}(\text { Organizational ambidexterity, Organizational design }) \\
\mathrm{OP}=\beta 0_{1}+\beta_{1} \mathrm{OA}+\varepsilon_{0} \\
\mathrm{OD}=\beta 0_{2}+\beta_{2} \mathrm{OA}+\varepsilon_{2} \\
\mathrm{OP}=\beta 0_{3}+\beta_{3} \mathrm{OD}+\varepsilon_{3} \\
\mathrm{OP}=\beta 0_{4}+\beta 0_{4} \mathrm{OA}+\beta 0_{5} \mathrm{OD}+\varepsilon_{4}
\end{gathered}
$$

Where:

$\mathrm{OP}=$ Aggregate mean score (composite) of Organizational Performance perspectives

$\beta 0_{1 \ldots} \ldots 0_{5} ; \beta_{1 \ldots} \beta_{3}$ are regression coefficients

$\mathrm{OA}=$ Aggregate mean of the combined Individual organizational ambidexterity indicators

$\mathrm{OD}=$ Aggregate mean of the combined Individual organizational design indicators

$\varepsilon_{0} \ldots \varepsilon_{4}=$ Error term

\section{Research Methodology}

\subsection{Research Philosophy and Design}

The study was grounded on the positivist philosophy. Cross-sectional survey design permits statistical analysis of the data collected and facilitates hypotheses testing establishing existence/non-existence of significant spot-on among variables relationships, thus study appropriateness. A cross-sectional survey design is associated with the deductive approach which seeks to explain causal relationships. This design helps in the outcomes generalization to a bigger population of organizations rather than the few that participated in the study.

\subsection{Population of the Study}

The study was a census, with the population being all the 107 Kenyan LMFs. KAM (2018) classifies manufacturing companies with 50 and above employees and annual sales turnover of Kshs 1 Billion and above as large. The 
definition was adopted for purposes of this study. The similarity of the Kenyan conditions under which the study was conducted made the number of employees and sales revenue appropriate in size determination.

\subsection{Data Collection}

The study collected primary and ancillary data. A structured questionnaire was the tool for primary data collection. Questionnaires were adapted from strategic management studies. These were modified to align with the current study objectives.

The questionnaire was delivered to the Managing Directors/Chief Executive Officers (MDs/CEOs) of the firms or with their permission, General Managers(GMs) or Heads of department (HODs) of Finance, Sales and Marketing, Human Resources and production. Organizations' key informants and typically most responsible and familiar with the organization's performance parameters are the CEOs and HODs. The questionnaire administration was by dropping and picking or sending by e-mail in cases where firms' e-mail addresses had been provided in the Kenya Association of Manufacturers (KAM) directory or in accordance with the preference of the respondents.

\subsection{Validity and Reliability Tests}

The research questionnaire was adopted from existing literature, and customized for current study objectives alignment.The thorough review and verification of extant literature ensured that items needed for measuring the concepts were incorporated. Further, the understanding of the questions by the respondents was assessed during the pilot study. A randomly selected 5(five) firms from the study population were used in the questionnaire pretesting pilot study. The feedback collected guided review of the data collection questionnaire, and also helped avoid comprehension problem, therefore improving the questionnaire suitability. Finally, the returned questionnaires were thoroughly checked to ensure their consistency and completeness after data collection. Only valid questionnaires were used in the analysis.

The research questions were tested against test items for internal consistency through reliability tests and this informs replicability. Furthermore, research assistants were trained on objectivity in results scoring, while the researcher ensured that the same questions in the questionnaire were presented to all the respondents, therefore enhancing consistency.

\section{Data Analysis and Results}

\subsection{Tests of Hypotheses}

The research objective was to determine whether organizational design mediates the relationship between organizational ambidexterity and performance of large manufacturing firms in Kenya. The objective was actualized by testing the hypothesis $\left(\mathrm{H}_{1}\right)$ that "Organizational design has no mediating role in the influence of organizational ambidexterity on the performance of large manufacturing firms in Kenya". Four-step path analysis proposed by Baron and Kenny (1986) was employed to test the hypothesis. The Baron - Kenny's technique consists of four steps and related conditions that must be satisfied. Simple linear regression analysis was applied in steps one to three while step four involved the use of multiple regression analysis.

Organizational performance was operationalized and measured as a composite of the six perspectives in the SBSC approach. The mediation tests are conducted based on performance measured as a composite of the SBSC perspectives. The findings are presented in Table 1.

Table 1. Regression outcomes for the mediation role of organizational design in the relationship between organizational ambidexterity and organizational performance

\begin{tabular}{lllll}
\hline \multicolumn{7}{c}{ Model Summary } \\
\hline $\begin{array}{l}\text { Mode } \\
1\end{array}$ & $\mathrm{R}$ & R Square & $\begin{array}{l}\text { Adjusted } \\
\text { R Square }\end{array}$ & $\begin{array}{l}\text { Std. Error } \\
\text { of the } \\
\text { Estimate }\end{array}$ \\
\hline 1 & $.589^{\mathrm{a}}$ & .347 & .341 & .16877 \\
\hline 2 & $.430^{\mathrm{a}}$ & .185 & .176 & .22611 \\
\hline 3 & $.562^{\mathrm{a}}$ & .316 & .309 & .17282 \\
\hline 4 & $.681^{\mathrm{a}}$ & .464 & .453 & .15373 \\
\hline
\end{tabular}




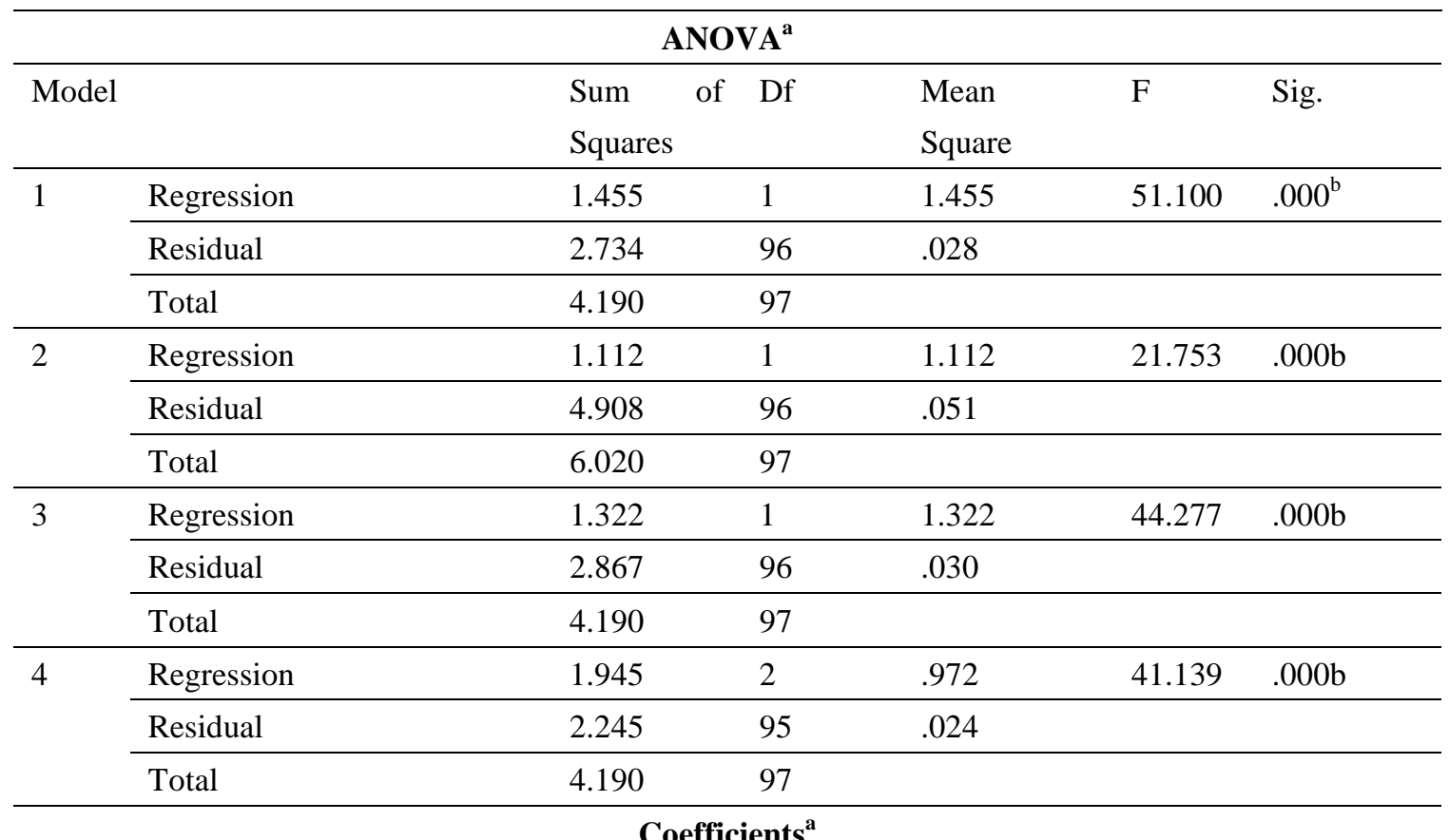

\begin{tabular}{|c|c|c|c|c|c|c|}
\hline \multicolumn{2}{|c|}{ Model } & \multirow{2}{*}{\multicolumn{2}{|c|}{$\begin{array}{l}\text { Unstandardized } \\
\text { Coefficients }\end{array}$}} & \multirow{3}{*}{$\begin{array}{l}\text { Standardized } \\
\text { Coefficients } \\
\text { Beta }\end{array}$} & \multirow[t]{3}{*}{$\mathrm{T}$} & \multirow[t]{3}{*}{ Sig. } \\
\hline & & & & & & \\
\hline & & B & $\begin{array}{l}\text { Eta. } \\
\text { Error }\end{array}$ & & & \\
\hline \multirow[t]{3}{*}{1} & (Constant) & 1.994 & .265 & & 7.537 & .000 \\
\hline & Organizational & .494 & .069 & .589 & 7.148 & .000 \\
\hline & Ambidexterity & & & & & \\
\hline \multirow[t]{3}{*}{2} & (Constant) & 2.196 & .354 & & 6.197 & .000 \\
\hline & Organizational & .432 & .093 & .430 & 4.664 & .000 \\
\hline & Ambidexterity & & & & & \\
\hline \multirow[t]{2}{*}{3} & (Constant) & 2.078 & .271 & & 7.657 & .000 \\
\hline & Organizational Design & .469 & .070 & .562 & 6.654 & .000 \\
\hline \multirow[t]{4}{*}{4} & (Constant) & 1.301 & .285 & & 4.562 & .000 \\
\hline & Organizational Design & .357 & .070 & .427 & 5.130 & .000 \\
\hline & Organizational & .316 & .069 & .378 & 4.549 & .000 \\
\hline & Ambidexterity & & & & & \\
\hline
\end{tabular}

Model 1: Predictors (Constant), Organizational Ambidexterity: Dependent variable Organizational Performance.

Model 2: Predictors (Constant), Organizational Ambidexterity: Dependent variable Organizational Design.

Model 3: Predictors (Constant), Organizational Design: Dependent variable Organizational Performance. Model 4: Predictors (Constant), Organizational Ambidexterity, Organizational Design: Dependent variable Organizational Performance.

Step one in the path analysis requires the testing of the relationship between the dependent and the independent variable. Proceeding to step two is dependent on whether or not there is a significant relationship between the 
independent variable and the dependent variable. In the current study, the relationship between organizational ambidexterity (independent variable) and organizational performance (dependent variable) was assessed using simple linear regression analysis. The results in Table 1.1 show that in step one, the effect of organizational ambidexterity on organizational performance is significant $\left(R^{2}=0.347, F=51.100, p<0.05 ; \beta=0.589, t=7.148\right.$, $\mathrm{p}<0.05)$. The results show that 34.70 percent change in performance can be attributed to organizational ambidexterity $\left(\mathrm{R}^{2}=0.347\right)$, the rest (65.30 percent) of the change in performance is explained by other variables, not in the current study. The model beta coefficient is significant $(\beta=0.589, \mathrm{p}<0.05)$, thus evidence of the model predictive power. The first mediation condition requires that the independent variable should be significantly related to the dependent variable in the absence of the mediating variable. According to the results in Table 1.1, this requirement is fulfilled.

In step two in the path analysis mediator (Organizational design) is regressed on the independent variable (Organizational ambidexterity). The relationship between organizational ambidexterity and organizational design was analyzed using simple linear regression analysis. The findings are in Table 1.1. The findings indicate that the effect of organizational ambidexterity on organizational design is significant $\left(R^{2}=0.185, F=21.753, p<0.05 ; \beta=0.430\right.$, $\mathrm{t}=4.664, \mathrm{p}<0.05)$. The results show that 18.50 percent of the variation in organizational design can be explained by organizational ambidexterity $\left(\mathrm{R}^{2}=0.185\right)$, the rest $(81.50$ percent $)$ of the change in organizational design is explained by other variables, not in the current study. The F-value significance is an indication that the model goodness of fit and robustness, thus was suitable for analyzing the data for this study. The findings imply satisfaction of the second condition which requires that the independent variable should be significantly related to the mediator variable.

Step three of the path analysis calls for an evaluation of the relationship between the mediating variable and the dependent variable. This is only allowed if the relationship between the independent variable and the mediating variable in step two is significant, otherwise, the process terminates. The results in Table 1.1 demonstrate a significant relationship between organizational ambidexterity and organizational design, therefore enabling the proceeding to step three of path analysis. In step three, the relationship between the mediating variable and the dependent variable was analyzed using simple linear regression analysis. The results of the evaluation of the relationship between organizational design and organizational performance as presented in Table 1.1 reveal that the influence of organizational design on organizational performance was significant $\left(R^{2}=0.316, F=44.277, p<0.05\right.$; $\beta=0.4562, \mathrm{t}=6.654, \mathrm{p}<0.05$ ). This means that 31.60 percentage of change in organizational performance is explained by organizational design, the rest ( 68.40 percent) is explained by other variables, not in the current study. The significance of F-ratio is an indication that the regression model attained goodness of fit and thus suitable for analyzing the data for this study $(\mathrm{F}=44.227, \mathrm{p}<0.05)$. These results satisfy the third mediation condition which states that the mediator variable should be significantly related to the dependent variable.

The outcome of step three determines whether the process should move to the fourth and final step of path analysis. The results of step three indicate a significant relationship between organizational design and organizational performance. The findings cleared the way for step four of path analysis. Step four entails analysis of the relationship between the independent and the dependent variable when the effect of the mediating variable on the dependent variable is controlled. Multiple regression analysis was used to analyze the effect of organizational ambidexterity and organizational design together on organizational performance. The results as presented in Table 1.1 reveal that the influence of organizational ambidexterity (independent variable) on organizational performance (dependent variable) was significant $\left(\mathrm{R}^{2}=0.464, \mathrm{~F}=41.139, \mathrm{p}<0.05 ; \beta=0.378, \mathrm{t}=4.549, \mathrm{p}<0.05\right)$ in the presence of organizational design (mediator variable) whose influence is also significant $(\beta=0.427, t=51.130, p<0.05)$. The F-ratio is significant $(\mathrm{F}=41.139, \mathrm{p}<0.05)$.This is an indication that the regression model attained goodness of fit and thus was suitable for analyzing the data for this study.

The results in Table 1.1 indicate success in the first three steps. Further the results indicate that organizational ambidexterity has a smaller regression coefficient of 0.378 when both organizational ambidexterity and organizational design are used to predict organizational performance compared to that of 0.589 when organizational ambidexterity is used to predict organizational performance. The results provide evidence that the relationship between organizational ambidexterity and organizational performance is partially mediated by organizational design. The null hypothesis that organizational design has no mediating role in the influence of organizational ambidexterity on the performance of large manufacturing firms in Kenya is rejected. Hence, the conclusion that organizational design has a mediating role in the influence of organizational ambidexterity on the performance of large manufacturing firms in Kenya.

\section{Discussion of Findings}

The objective of the study was to determine the role of organizational design in the relationship between 
organizational ambidexterity and performance of large manufacturing firms in Kenya. The related hypothesis was: Organizational design does not mediate the influence of organizational ambidexterity on performance of large manufacturing firms in Kenya. This hypothesis was rejected. The study therefore concludes that organizational design has partial mediating role in the relationship between organizational ambidexterity and performance of large manufacturing firms in Kenya.

The study findings are in tandem with earlier related studies. Hill and Birkinshaw (2014) whose study on Corporate Venture units found a positive association between structural design and ambidextrous orientation development. Also, Boumgarden et al. (2012) in their study found structural designs (spatial separation) aids organizational ambidexterity and therefore enhances performance. Similarly, O'Reilly and Tushman (2011) reported a mediating effect of structural mechanisms linked with top management's integration on organizational ambidexterity and performance relationship. Further, Kariuki (2015) study findings established a significant impact of structure on the performance of large manufacturing companies in Kenya. These are in tandem with the current study finding that organizational design has a mediating role in the influence of organizational ambidexterity on performance of large manufacturing firms in Kenya.

The mediation findings support organizational configurations theory which posits that configuring the organization so that all these elements fit together with key strategic challenges including their environment, is critical to strategy implementation and organizational success (Mintzberg, 1979). The study findings show organizational design mediation role in the relationship between organizational ambidexterity and organizational performance. Due to the appropriate alignment of organizational design and the need for simultaneous undertaking of explorative and exploitative activities, large manufacturing firms in Kenya have experienced the indirect positive influence of organizational ambidexterity on their performance.

\section{Conclusion and Recommendations}

\subsection{Conclusion}

The study sought to determine the role of organizational design in the relationship between organizational ambidexterity and performance of large manufacturing firms in Kenya. The objective was actualized by testing the hypothesis that organizational design has no mediating role in the relationship between organizational ambidexterity and performance of large manufacturing firms in Kenya. The study rejected the null hypothesis leading to the conclusion that relationship between organizational ambidexterity and performance of large manufacturing firms in Kenya is partially mediated by organizational design. The study concludes that organizational design partially enables the easing of the tensions in the concurrent undertaking of exploration and exploitation activities. The synergetic effect of ambidexterity is felt, leading to the indirect positive effect on performance, partially through organizational design. Also, this finding led to the conclusion that appropriate alignment of organizational strategy with organizational design results to improved organizational performance. Further, the study concludes that organizational design can enhance or inhibit organizational ambidexterity thus affect performance.

\subsection{Theoretical and Conceptual Implications}

The study contributes towards the development of configurations theory. Configuration theory posits that designing the organization in ways that fit the implementation requirements of the organization's strategic initiative enhances performance (Mintzberg, 1979). It is therefore expected that the appropriate fit between configuration and context impacts performance positively.The study links organizational ambidexterity positive and significant influence on organizational performance to organizational configurations by confirming that organizational design has partial mediating role in the influence of organizational ambidexterity on performance of large manufacturing firms in Kenya.

The results demonstrate that large manufacturing firms in Kenya have put in place mixed organizational designs, as indicated by an average 5-point Likert-like scale score of 3.86. The mid-point of 3 was operationalized as mixed design and therefore the 3.86 average indicates mixed design with more elements of mechanistic designs. According to Raisch and Zimmermann (2017), the ambidexterity complementary effect in generating high performance is undermined by negative externalities created by organizational designs, hence a paradox. Large manufacturing firms in Kenya have implemented mixed organizational designs, which have enabled the partial mediating role of organizational design on the influence of organizational ambidexterity on performance. The study finding therefore affirm Adler et al. (1999) claim that firms may resolve the paradox by combining mechanistic and organic features. Hence, the study has conceptual implications on ambidexterity and organizational design concepts.

Scholars hold divergent views on organizational design as an enabler to organizational ambidexterity arguing that as 
much as duality may allow for separate unit- level focus and alignment, intra-organizational conflicts may emerge, and may lead to low performance (Doty, Glick \& Huber, 1993). The study findings that mixed designs partially mediate in the relationship between organizational ambidexterity and performance of organizations is a contribution to this debate on organizational design as an enabler of organizational ambidexterity in the relationship with organizational performance. Also, conceptualization and testing of organizational design contribute towards the cited limitation of instrumentation deficiency divergent research designs and analysis, and conflicting conceptualizations (Fiss, 2011), therefore aiding research on the impact of organizational configurations on performance (Ferguson \& Ketchen, 1999).

\subsection{Implications for Policy}

The research established that organizational design has partial mediation role in the relationship between organizational ambidexterity and performance of large manufacturing firms in Kenya. This is useful as policymakers are well guided on the organizational designs to ensure the benefits of organizational ambidexterity to be realized. The study established that large manufacturing firms in Kenya have mixed organizational designs; which the findings reported partially aid the concurrent performance of exploration and exploitation activities (organizational ambidexterity) with the resulting positive and significant effect on performance. The government policymakers could therefore put in place mechanisms to ensure strategy-organizational design alignment for the manufacturing sector.

\subsection{Implications for Management and Practice}

The research findings have implications for management and practice. The study reported partial mediating role of organizational design in the organizational ambidexterity-performance relationship. This implies that mixed organizational designs effectively reduce the related tensions of ambidexterity, including intra-organizational tensions and conflict. Management is therefore empowered on the requisite organizational design put in place for effective ambidexterity execution.

\subsection{Limitations of the Study}

This study was guided by positivist paradigm which is rooted in atomism, quantification and operationalization. Positivism has been criticized for failing to acknowledge that the world is fragmented with disorganized units that are distinct from each other and can only be critically understood through interactions. The positivist aim of measuring variables of social phenomena through quantification has also been criticized. Limitations of positivist's paradigm have no doubt crept into the study and its findings.

The study was based on cross-sectional survey design and therefore results based on data at a particular point in time. The study was limited in that change in various variables of study was not monitored or observed over time as would be the case with longitudinal studies. This is a limitation due to financial constraints preventing one from carrying out longitudinal studies over a period of time.

Data was collected mainly using a questionnaire in which respondents were required to rate, based on their opinions, statements on a Likert-like scale. There was only one respondent per firm. Although the use of only senior managers (CEOs/GMs/HODs) to respond to the questionnaires was expected to enhance objectivity, the limitation of single source bias cannot be completely eliminated. Also, the generalization of the results is limited since data was collected only from senior managers. The fact that the respondents were all at management level may have presented in the study the issue of social desirability bias and other self-presentational concerns which may have reduced the predictive power of the variables

In context, the study was done in Kenyan manufacturing firms only. The study was limited to large-scale manufacturing firms that were members of KAM.This excludes small, medium size manufacturing firms, large manufacturing firms who were not KAM members, as well as firms not in manufacturing sector. The context focus of the study therefore confines the probability of generalizing the research results. Although the sector/industry focus enhances internal validity, caution should be exercised when generalizing the results to other sectors/industries. It should be kept in mind that findings in large manufacturing firms sub-sector context may not necessarily translate into another sector context(s); for example financial services, telecommunication,transport,etc.

\subsection{Suggested Areas for Further Study}

The data in this research was collected from a single source. One senior manager (General Manager or Head of department) provided the data by responding to the questionnaire which covered the various variables of the research. Relying on a response from one person in a big organization may have some limitations; such as single source and social desirability bias. Future researchers should involve more people across the management hierarchy and in 
different settings such as focus groups.

It is recommended that future research considers incorporating the use of several types of data collection methods and techniques. This study was limited to the use of questionnaire only. As such, other data collection methods such as interviews, observations and case studies would be recommended. Future researchers could also consider operationalizing the study variables differently from the current approach. Cross sectional research design was used as the research design. Future researchers can consider longitudinal design to overcome the limitations of cross sectional research design by providing the impact of organizational ambidexterity on organizational performance over time and to establish causal relationships.

The variables in the study may be operationalized and measured differently by different scholars given the importance of the situation at hand. Future research should consider research specific components of organizational ambidexterity, organizational design, and organizational performance, as this may provide more distinct results in terms of specific variables that should be given more focus.

This study was based on large manufacturing firms in Kenya. The study can be replicated in other African countries to determine the similarities or differences. Also, research should be conducted in small and medium manufacturing firms in Kenya. Further, future researchers should conduct a comparative study, replicating this study in a big population covering many industries. Such large population would be a useful extension of this study and would further enrich the current findings.

\section{Acknowledgements}

I wish to convey my special sincere thanks to my supervisors, Prof. Peter K'Obonyo, Dr.Kennedy Ogollah and Prof. James M. Njihia for their incredible support, guidance and encouragement as I did this study. I would like to thank them for being patient with me during the many hours of consulting them that enabled me to reach the final stages of the program. The many hours they spent critiquing, correcting and giving me wise counsel on how to proceed have enabled to get this far. My supervisors were truly patient with me and I would like to thank them very much.

\section{References}

Adler, P. S., Goldoftas, B., \& Levine, D. I. (1999). Flexibility versus Efficiency? A Case Study of Model Changeovers in the Toyota Production System. Organization Science, 10(1), 43-68. https://doi.org/10.1287/orsc.10.1.43

Akdogan, S., Akdogan, A. A., \& Cingoz, A. (2009). Organizational Ambidexterity: An empirical examination of Organizational factors as antecedents of organizational ambidexterity. Journal of Global Strategic Management, 6, 6-27. https://doi.org/10.20460/JGSM.2009318458

Baron, R. M., \& Kenny, D. A. (1986). The Moderator-Mediator Variable Distinction in Social Psychological Research: Conceptual, Strategic, and Statistical Considerations. Journal of Personality and Social Psychology, 51(6), 1173-1182. https://doi.org/10.1037/0022-3514.51.6.1173

Birkinshaw, J., \& Gupta, K. (2013). Clarifying the distinctive contribution of ambidexterity to the field of organization studies. The Academy of Management Perspectives, 27(4), 287-298. https://doi.org/10.5465/amp.2012.0167

Blindenbach-Driesen, F., \& Ende, J. (2014). The Locus of Innovation: The Effect of a Separate Innovation Unit on Exploration, Exploitation, and Ambidexterity in Manufacturing and Service Firms. Journal of Product Innovation Management, 31(5), 1089-1105. https://doi.org/10.1111/jpim.12146

Boumgarden, P., Nickerson, J., \& Zenger, T. R. (2012). Sailing into the wind: Exploring the relationships among ambidexterity, vacillation, and organizational performance. Strategic Management Journal, 33(6), 587-610. https://doi.org/10.1002/smj.1972

Doty, H. D., Glick, W. H., \& Huber, G. P. (1993). Fit, Equifinality, and Organizational Effectiveness: A Test of Two Configurational Theories. Academy of Management Journal, 36(6), 1196-1250. https://doi.org/10.2307/256810

Ferguson, T. D., \& Ketchen, D. J. (1999). Organizational Configurations and Performance: The Role of Statistical Power in Extant Research. Strategic Management Journal, 20(4), 385-395. https://doi.org/10.1002/(SICI)1097-0266(199904)20:4<385::AID-SMJ24>3.0.CO;2-X

Fiss, P. C. (2011). Building better causal theories: A fuzzy set approach to typologies in organization research. Academy of Management Journal, 54(2), 393-420. https://doi.org/10.5465/amj.2011.60263120

Ghemawat, P., \& Ricart Costa, J. E. (1993). The organizational tension between static and dynamic efficiency. 
Strategic Management Journal, 14(S2), 59-73. https://doi.org/10.1002/smj.4250141007

Government of Kenya. (2018).

Hill, S. A., \& Birkinshaw, J. (2014). Ambidexterity and survival in corporate venture units. Journal of Management, 40(7), 1899-1931. https://doi.org/10.1177/0149206312445925

Hubbard, G. (2009). Measuring organizational performance: Beyond the triple bottom line. Business Strategy and Environment, 19, 177-191. https://doi.org/10.1002/bse.564

Jansen, J. P., Simsek, Z., \& Cao, Q. (2012). Ambidexterity and Performance in Multiunit Contexts: Cross-Level Moderating Effects of Structural and Resource Attributes. Strategic Management Journal, 33, 1286-1303. https://doi.org/10.1002/smj.1977

Junni, P., Sarala, R. M., Taras, V., \& Tarba, S. Y. (2013). Organizational ambidexterity and performance: A' meta-analysis. The Academy of Management Perspectives, 27(4), 299-312. https://doi.org/10.5465/amp.2012.0015

Kariuki, P. M. (2015). Organizational Structure and Internal Processes of Large Manufacturing Firms in Kenya. Journal for Studies in Management and Planning, 1(7), 613-622.

Kenya Association of Manufacturers. (2018). Kenya manufacturers and exporters directory. Nairobi: KAM.

Kenya National Bureau of Statistics. (2019). Economic Survey Report.

Lawrence, P. R., \& Lorsch, J. W. (1967). Differentiation and integration in complex organizations. Administrative Science Quarterly, 1-47. https://doi.org/10.2307/2391211

March, J. G. (1991). Exploration and exploitation in organizational learning. Organization Science, 2(1), 71-87. https://doi.org/10.1287/orsc.2.1.71

Marks, M. A., Mathieu, J. E., \& Zaccaro, S. J. (2001). A temporally based framework and taxonomy of team processes. Academy of Management Review, 26(3), 356-376. https://doi.org/10.5465/amr.2001.4845785

Mintzberg, H. (1979). The structuring of organizations. Prentice-Hall Inc., New Jersey, USA.

O’Reilly, C. A., \& Tushman, M. L. (2008). Ambidexterity as a Dynamic Capability: Resolving the Innovator's Dilemma. Research in Organizational Behaviour, 28, 185-206. https://doi.org/10.1016/j.riob.2008.06.002

O'Reilly, C. A., \& Tushman, M. L. (2011). Organizational ambidexterity in action: How managers explore and exploit. California Management Review, 53(4), 5-22. https://doi.org/10.1525/cmr.2011.53.4.5

O’Reilly, C. A., \& Tushman, M. L. (2013). Organizational Ambidexterity: Past, Present, and Future. The Academy of Management Perspectives, 27(4), 324-338. https://doi.org/10.5465/amp.2013.0025

Ogollah, K. O. (2012). Organizational configuration, stage of development and performance of Commercial banks in Kenya. An Unpublished PhD Thesis, University of Nairobi.

Raisch, S., \& Birkinshaw, J. (2008). Organizational ambidexterity: Antecedents, outcomes, and moderators. Journal of Management, 34(3), 375-409. https://doi.org/10.1177/0149206308316058

Raisch, S., \& Zimmermann, A. (2017). The Oxford Handbook of Organizational Paradox. Oxford University Press.

Venkatraman, N., Lee, C. H., \& Lyer, B. (2007). Strategic ambidexterity and sales growth: A longitudinal test in the software sector. In Unpublished Manuscript (earlier version presented at the Academy of Management Meetings, 2005).

\section{Copyrights}

Copyright for this article is retained by the author(s), with first publication rights granted to the journal.

This is an open-access article distributed under the terms and conditions of the Creative Commons Attribution license (http://creativecommons.org/licenses/by/4.0/). 